\title{
Ultrasound call detection in capybara ${ }^{1}$
}

\author{
Selene S.C. Nogueira ${ }^{2 *}$, Kamila S. Barros ${ }^{2}$, Márcio H. Almeida ${ }^{3}$, Janine P. Pedroza², \\ Sérgio L.G. Nogueira Filho ${ }^{2}$ and Rosana S. Tokumaru
}

\begin{abstract}
Nogueira S.S.C., Barros K.S., Almeida M.H., Pedroza J.P., Nogueira Filho S.L.G. \& Tokumaru R.S. 2012. Ultrasound call detection in capybara. Pesquisa Veterinária Brasileira 32(7):663-666. Laboratório de Etologia Aplicada, Departamento de Ciências Biológicas, Universidade Estadual de Santa Cruz, Rodov. Ilhéus-Itabuna Km 16, Ilhéus, BA 45662 900, Brazil. E-mail: seleneuesc@gmail.com

The vocal repertoire of some animal species has been considered a non-invasive tool to predict distress reactivity. In rats ultrasound emissions were reported as distress indicator. Capybaras' vocal repertoire was reported recently and seems to have ultrasound calls, but this has not yet been confirmed. Thus, in order to check if a poor state of welfare was linked to ultrasound calls in the capybara vocal repertoire, the aim of this study was to track the presence of ultrasound emissions in 11 animals under three conditions: 1) unrestrained; 2) intermediately restrained, and 3 ) highly restrained. The ultrasound track identified frequencies in the range of $31.8 \pm 3.5 \mathrm{kHz}$ in adults and $33.2 \pm 8.5 \mathrm{kHz}$ in juveniles. These ultrasound frequencies occurred only when animals were highly restrained, physically restrained or injured during handling. We concluded that these calls with ultrasound components are related to pain and restraint because they did not occur when animals were free of restraint. Thus we suggest that this vocalization may be used as an additional tool to assess capybaras' welfare.
\end{abstract}

INDEX TERMS: Animal restraint, animal welfare, Hydrochoerus hydrochaeris, capybara, ultrasonic vocalization, wildlife management.

RESUMO.- [Detecção de chamados de ultrassom em capivara.] 0 repertório vocal de algumas espécies de animais tem sido considerado uma ferramenta não invasiva para predizer o distresse. Em ratos, emissões de ultrassom foram registradas como indicador de distresse. 0 repertório vocal de capivaras foi relatado recentemente e parece haver a presença de chamados em ultrassom que ainda não foram confirmados. Assim para associar o estado de bem-estar empobrecido em capivaras e a possibilidade de ocorrência de ultrassom em seu repertório vocal, o presente estudo teve como objetivo rastrear a presença deste tipo de vocalização em 11 animais submetidos a três condições diferentes: 1) sem contenção; 2) média contenção e 3) alta contenção. 0 rastreamento revelou a presença de faixas de

\footnotetext{
${ }^{1}$ Received on March 6, 2012.

Accepted for publication on April 10, 2012.

${ }^{2}$ Laboratório de Etologia Aplicada, Departamento de Ciências Biológiocas, Universidade Estadual de Santa Cruz (UESC), Campus Soane Nazaré de Andrade, Rodovovia Ilhéus-Itabuna Km 16, Ilhéus, BA 45662-900, Brazil. *Corresponding author: selene.nogueira@pq.cnpq.br

${ }^{3}$ Departamento de Psicologia Social e do Desenvolvimento, Universidade Federal de Espírito Santo, Av. Fernando Ferrari 514, Goiabeiras, Vitória, ES 29073-910, Brazil.
}

frequência de $31,8 \pm 3,5 \mathrm{kHz}$ em adultos e $33,2 \pm 8,5 \mathrm{kHz}$ em filhotes. Estas emissões encontradas na faixa de ultrassom ocorreram apenas durante a alta contenção, quando contidos fisicamente ou feridos durante o manejo. Concluímos que tais emissões, com componentes de ultrassom, estão relacionadas à dor e ao distresse de contenção pois não ocorreram quando os animais estavam livres de contenção. Assim sugerimos que esta vocalização pode ser usada como uma ferramenta adicional para acessar o estado de bem-estar em capivaras.

TERMOS DE INDEXAÇÃO: Bem-estar animal, contenção animal, Hydrochoerus hydrochaeris, capivara, manejo de animais selvagens, vocalização de ultrassom.

\section{INTRODUCTION}

Captive breeding of capybaras, Hydrochoerus hydrochaeris (Linnaeus, 1766) is on the increase in Neotropical countries, due to a demand for meat and leather (Nogueira-Filho \& Nogueira 2004). The welfare of livestock has received increased research attention in recent years (Fraser \& Duncan 1998, Boissy et al. 2007). Nevertheless, few studies have reported the behavioral response of Neotropical wild animals under farming conditions (Nogueira et al. 2010, 
2011). Management procedures often provide some kind of stress associated to distress vocalizations, as reported in pigs (White et al. 1995, Moura et al. 2008) and cattle (Grandin 1998).

Recent studies on captive capybaras' vocalizations showed important knowledge about this species' communication, describing their vocal repertoire (Barros 2009, Barros et al. 2011). Most capybaras sounds are audible to humans. However, the spectrograph analysis of these vocalizations showed high component frequencies, above $20 \mathrm{kHz}$, suggesting the occurrence of ultrasound calls (Barros 2009).

In rats, ultrasound emissions have been related to negative situations, such as predator detection (Blanchard et al. 1991, Wöhr \& Schwarting 2007), isolation distress (Naito et al. 2000, Borges et al. 2010), exposure to cold (Blumberg \& Stolba 1996) and defense/subordinate behavior (Thomas et al. 1983). Many studies are applying bioacoustics information as a non-invasive tool to predict distress reactivity (Drugan et al. 2009, Tolon et al 2010). However, to date no information on capybara ultrasonic calls is available to confirm Barros' (2009) hypothesis. This occurrence, if confirmed, may provide advances in capybara biology knowledge, and improvements in species welfare, helping to detect poor welfare in medical procedures, for instance.

Thus, the aim of this study was to track and spectrographically describe ultrasound vocalization in captive capybaras, to confirm Barros' (2009) hypothesis. In addition, as this vocalization is related to situations of distress, this study was carried out during three restrained conditions: unrestrained, intermediately restrained and highly restrained, to associate this type of call emission with any invasive conditions.

\section{MATERIALS AND METHODS}

From September to November, 2008, we monitored ultrasound emissions from 11 capybaras (four juveniles between four and five months old, and seven adults about three years old). Animals were housed in a $4,000 \mathrm{~m}^{2}$ paddock at the Laboratory of Applied Ethology (LABet), Universidade Estadual de Santa Cruz (UESC), Ilhéus, Bahia, Brazil (1447'39.8'S, 39¹0'27.7'W). The paddock had a corral-trap, used as feeding and handling area, measuring $25 \mathrm{~m}^{2}(10 \times 2.5 \mathrm{~m})$, surrounded by a $1.8 \mathrm{~m}$ high wire fence with two guillotine doors.

The ultrasound tracking occurred between $07 \mathrm{~h} 00$ and $10 \mathrm{~h} 00$ under three different conditions: 1) unrestrained (C1), when individuals were free in their paddock; 2) intermediately restrained (C2), when the individuals were trapped inside the corral-trap and 3) highly restrained (C3), when individuals were introduced into the cage trap or captured by net for ordinary management procedures. In the highly restrained condition (condition 3 ) the focal animal was allocated to a cage trap by its keeper, passing first through a small corridor connected to the cage trap. Following, the veterinarian handled the animal for examinations, reaching through the cage. To restrain juveniles, we employed a net instead of the cage trap.

The data collection was carried on 10 non-consecutive days. The observational session in C1 lasted one hour during daylight, totaling four hours of observation under this condition. Both conditions C2 and C3 were observed during ordinary veterinary proceedings at LABET. No animal was placed under these conditions for the sole purpose of tracking ultrasound calls, due to welfare concerns. All subjects tested had a real management need. The management activities involved standard, pre-scheduled veterinarian procedures, such as sex determination, anti-parasitism measures or treatment of injury carried out by a keeper and a veterinarian.

In C1 the ultrasound detector stayed on for intervals of $10 \mathrm{mi}-$ nutes during the observational sessions while animals displayed their behavioral activities, such as moving, resting, and feeding. In $\mathrm{C} 2$ and $\mathrm{C} 3$, the ultrasound detection began one minute after the animals had entered the corral trap, the cage trap or the net, and finished when they were released into the paddock.

To record ultrasound calls a Pettersson ultrasound detector D240 (Pettersson Elektronik A B) was employed, tuned to 35 $\mathrm{kHz}$ in the Heterodyne mode for monitoring the ultrasound vocalizations of the capybaras. The Pettersson frequency detection capability ranges from 10 to $120 \mathrm{kHz}$. The ultrasound emissions detected were sampled $(1.7 \mathrm{~s} / \mathrm{sample})$ in the time expansion mode $(10 \mathrm{x})$ and recorded in a DAT recorder (Marantz model PMD-670).

The data analysis was described by using bioacoustics parameters. The spectrographs were generated and analyzed by using Avisoft-SASLab pro software (version 4.3). To describe the vocalization properties we identified and measured the following spectral parameters - minimum frequency, maximum frequency, inter-element intervals, number of harmonics and note duration. The characterization of an unknown call is important as a standard pattern or guidance for further notifications and evaluation. To certify that the ultrasound calls detected came from the capybaras and not from artifacts due to the animals' movements or human activity during recording, the same handling procedures without animals were simulated.

\section{RESULTS}

We detected 12 calls, six from two juveniles and six from one adult. Within those, eight calls presented ultrasound components (Table 1, Fig.1). Two emissions from juveniles showed ultrasound components with maximum frequencies of 25.3 and $33.2 \mathrm{kHz}$. The adult emitted six ultrasound calls, with the maximum frequencies ranging from 23.9 $\mathrm{kHz}$ to $31.8 \mathrm{kHz}$ (Table 1). The detected ultrasounds calls occurred during $\mathrm{C} 3$, when the animals were highly restrained. This condition included sex determination of juveniles; during this procedure the veterinarian needs to touch the animal's pelvic area and to evert its penis. While veterinarian replace plastic ear tags, adult individuals pushed against the cage trap trying to escape, so that some hurt their head and bled.

\section{DISCUSSION AND CONCLUSION}

Although no studies about the hearing ranges of capybaras are available, accurate hearing is expected in this species, since researchers have reported seven vocalizations in its vocal repertoire, including alarm calls and contact calls (Ojasti 1973, Yáber \& Herrera 1994, Barros et al. 2011). This study recorded additional ultrasonic vocalizations in adult and juvenile capybaras, confirming Barros et al.'s (2009) hypothesis. These ultrasonic vocalizations were associated with distress or pain because they were detected only under a highly restrained condition - C3. In rats, ultrasound emissions have been related to distinct emotional states (Cuomo et al. 1992, Knutson et al. 2002). 
Table 1. Acoustic parameters of the sounds emitted by juvenile and adult capybaras, under a highly restrained condition during medical procedures, registered with the use of an ultrasound detector during observations carried out from September to November 2008

\begin{tabular}{cccccc}
\hline $\begin{array}{c}\text { Age } \\
\text { category }\end{array}$ & $\begin{array}{c}\text { Minimum } \\
\text { frequency } \\
(\mathrm{kHz})\end{array}$ & $\begin{array}{c}\text { Maximum } \\
\text { frequency } \\
(\mathrm{kHz})\end{array}$ & $\begin{array}{c}\text { Sound duration } \\
(\mathrm{s})\end{array}$ & $\begin{array}{c}\text { Inter-element } \\
\text { interval (s) }\end{array}$ & $\begin{array}{c}\text { Number of } \\
\text { harmonics }\end{array}$ \\
\hline Juvenile & 2.3 & 18 & 0.03 & 1.28 & 6 \\
Juvenile & 2.8 & 7.9 & 0.04 & 0.17 & 3 \\
Juvenile & 6.0 & 17.8 & 0.06 & 0.21 & 5 \\
Juvenile & 2.3 & 17.8 & 0.03 & - & 6 \\
Juvenile & 2.3 & 33.2 & 0.20 & 0.52 & 10 \\
Juvenile & 3.2 & 25.3 & 0.25 & - & 8 \\
Mean( \pm SD & $3.2( \pm 1.4)$ & $20.0( \pm 8.5)$ & $0.10( \pm 0.03)$ & $0.54( \pm 0.52)$ & $6.3( \pm 2.4)$ \\
Adult & 6.0 & 23.9 & 0.12 & 0.25 & 10 \\
Adult & 5.1 & 30.0 & 0.11 & 0.29 & 17 \\
Adult & 6.0 & 24.8 & 0.09 & 0.47 & 13 \\
Adult & 2.7 & 31.2 & 0.23 & - & 17 \\
Adult & 4.2 & 25.3 & 0.00 & 0.45 & - \\
Adult & 5.1 & 31.8 & 0.00 & - & 11 \\
Mean( \pm SD & $4.9( \pm 1.2)$ & $27.8( \pm 3.5)$ & $0.09( \pm 0.09)$ & $0.37( \pm 0.11)$ & $13.6( \pm 3.29)$
\end{tabular}

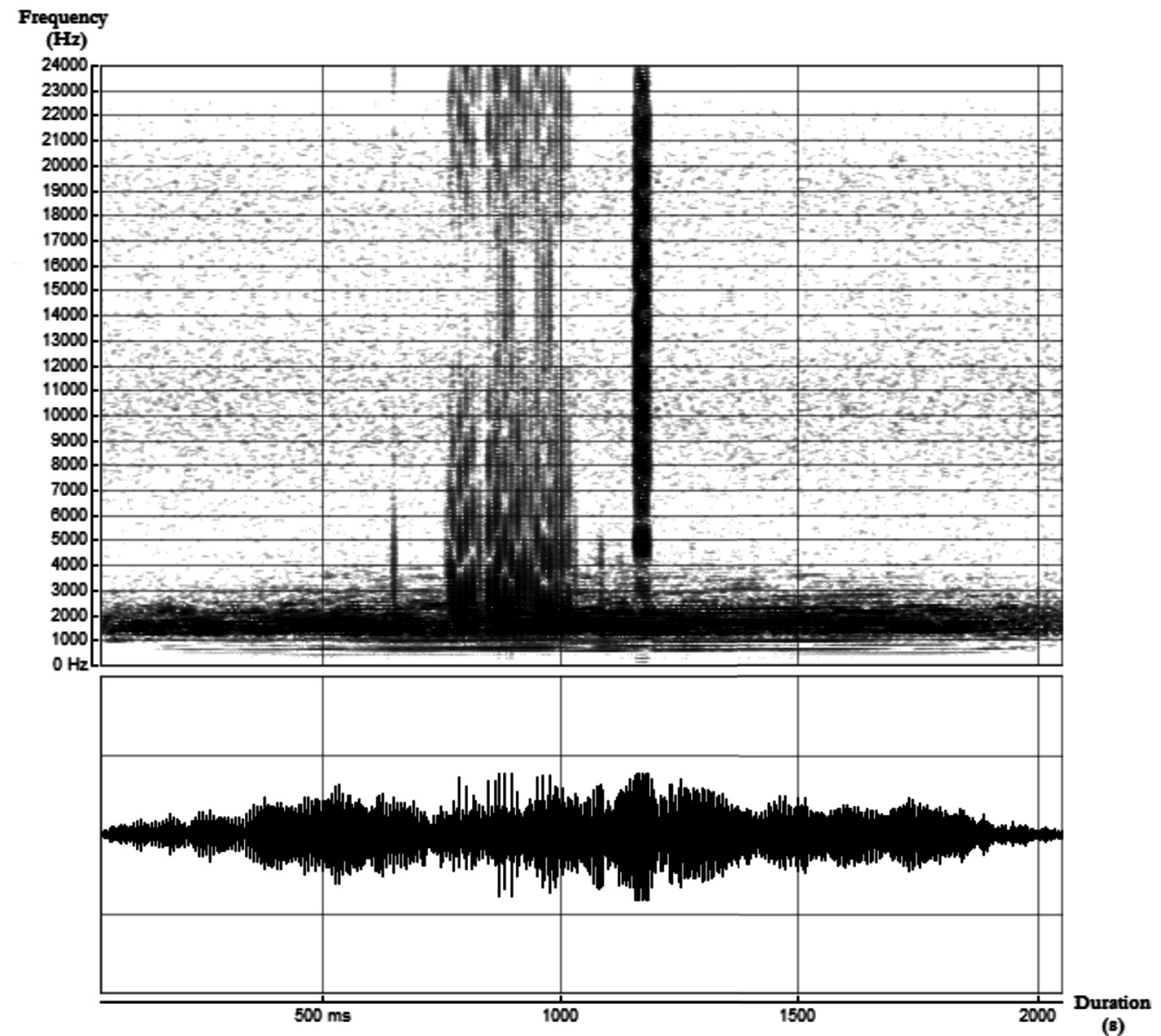

Fig.1. Spectrograph of one sample of $24 \mathrm{kHz}$ ultrasonic call in adult capybara recorded at the Laboratory of Applied Ethology, UESC, during veterinarian restraint for medical procedures (20th September 2008).

Besides rodent species and ultrasound emissions, vocal cues have been widely studied as a non-invasive tool to indicate welfare quality (Weary \& Fraser 1995, Moura et al. 2008). The capybara is a wild Neotropical species that has been bred in captivity for conservation or game purposes in many Latin American countries including Brazil; the findings reported here will provide animal keepers and ve- terinarians with a basis for technical improvements in the evaluation of species welfare.

Our study detected the ultrasound components in a very particular negative situation for capybaras. The presence of ultrasound vocalizations in this species will help other studies and medical procedures to track capybaras' stress and pain. The structural parameters described here, such 
as frequencies ranges, inter-element intervals and sound duration, will help researchers and physicians to compare and check particularities of sounds during medical procedures. Thus the confirmation of ultrasound components in the capybara repertoire will be useful as a cue and a tool to measure species welfare.

Acknowledgements.- To Prof. C. Ades for lending the Avisoft-SAS Lab Pro (version 4.3) software. Appreciation is also extended to Dr. P.F. Monticelli and Prof. D. Demolin for their help with ultrasound spectrograph. Sérgio Nogueira-Filho and Selene Nogueira were supported by the CNPq (Proc.300587/2009-0 and 306154/2010-2, respectively). K.S.B. and J.P.P. were supported by CAPES. This study was supported by CNPq (Proc.470068/2003-5), FAPES (Proc.311.828.01/2005): CAPES/PNPD (Proc.749-2010) and PROCAD-NF (Proc.749/2010). This work was approved by the Animal Ethics Committee of the Universidade Estadual de Santa Cruz (Proc.003/07).

\section{REFERENCES}

Barros K.S. 2009. Comunicação em capivaras: estrutura acústica e contexto comportamental. Dissertação apresentada ao PPG Zoologia, Universidade Estadual de Santa Cruz, Ilhéus, BA.

Barros K.S., Tokumaru R.S., Pedroza J.P. \& Nogueira S.S.C. 2011. Vocal repertoire of captive capybara (Hydrochoerus hydrochaeris): Structure, context and function. Ethology 117: 83-93.

Blanchard R.J., Blanchard D.C., Agullana R. \& Weiss S.M. 1991. Twenty-two $\mathrm{kHz}$ alarm cries to presentation of a predator, by laboratory rats living in Visible Burrow Systems. Physiol. Behav. 50:967-972.

Blumberg M.S. \& Stolba M.A. 1996. Thermogenesis, myoclonic twitching, and ultrasonic vocalization in neonatal rats during moderate and extreme cold exposure. Behav. Neurosci. 110:305-314.

Boissy A., Manteuffel G., Jensen M.B., Moe R.O., Spruijt B., Keeling L.J., Winckler C., Forkman B., Dimitrov I., Langbein J., Bakken M., Veissier I. \& Aubert A. 2007. Assessment of positive emotions in animals to improve their welfare. Physiol. Behav. 92:375-397.

Borges G., Silva K.O., Rodrigues V.C. \& Risi N. 2010. Uso da geoestatística para avaliar a captação automática dos níveis de pressão sonora em instalações de creche para suínos. Engenharia Agrícola 30:377-385. (Impresso)

Cuomo V., Cagiano R., De Salvia M.A., Mazzoccoli M., Persichella M. \& Renna G. 1992. Ultrasonic vocalization as an indicator of emotional state during active avoidance learning in rats. Life Sci. 50:1049-1055.

Drugan R.C., Christianson J.P., Stine W.W. \& Soucy D.P. 2009. Swim stress-induced ultrasonic vocalizations forecast resilience in rats. Behav. Brain Res. 202:142-145.
Fraser D. \& Duncan I.J.H. 1998. 'Pleasures', 'pains' and animal welfare: Toward a natural history of affect. Anim. Welf. 7:383-396.

Grandin T. 1998. The feasibility of using vocalization scoring as an indicator of poor welfare during cattle slaughter. Appl. Anim. Behav. Sci. 56:121-128.

Knutson B., Burgdorf J. \& Panksepp J. 2002. Ultrasonic vocalizations as indices of affective states in rats. Psychol. Bull. 128:961-977.

Moura D. J., Silva W.T., Nääs I.A., Tolon Y.B., Lima K.A.O. \& Vale M.M. 2008. Real time computer stress monitoring of piglets using vocalization analysis. Computers and Electronics in Agriculture, Leuven, 64:11-18.

Naito H., Noue I. \& Makino J. 2000. Ultrasonic isolation calls in genetically high- and low-emotional rat pups. Exp. Anim. 49(4):289-294.

Nogueira S.S.C., Calasans S.G., Costa T.S.O., Peregrino H. \& Nogueira-Filho S.L.G. 2011. Effects of varying feed provision on behavioral patterns of farmed collared peccary (Mammalia, Tayassuidae). Appl. Anim. Behav. Sci. 132:193-199.

Nogueira S.S.C., Silva M.G., Dias C.T.S., Pompeia S., Cetra M. \& Nogueira-Filho S.L.G. 2010. The social response of Collared Peccary (Pecari tajacu) under three space allowances. Anim. Welf. 19:243-248.

Nogueira-Filho S.L.G. \& Nogueira S.S.C. 2004. Captive breeding programs as an alternative for wildlife conservation in Brazil, p.171-190. In: Silvius K., Bodmer R. \& Fragoso J. (Eds), People in Nature, Wildlife Conservation in South and Central America. Columbia University Press, USA.

Ojasti J. 1973. Estudio Biológico del Chigüiro o Capibara. Fondo Nacional de Investigaciones Agropecuárias, República de Venezuela, Caracas.

Reynolds J.C. 2004. Trade-offs between welfare, conservation, utility and economics in wildlife management: A review of conflicts, compromises and regulation. Anim. Welfare 13:133-138.

Thomas D.A., Takahashi L.K. \& Barfield R.J. 1983. Analysis of ultrasonic vocalizations emitted by intruders during aggressive encounters among rats (Rattus norvegicus). J. Comp. Physiol. Psychol. 97:201-206.

Tolon Y.B., Baracho M.S., Naas I.A., Rojas M. \& Moura D.J. 2010. Ambiências térmica, aérea e acústica para reprodutores suínos. Engenharia Agrícola 30:1-13. (Impresso)

Weary D.M. \& Fraser D. 1995. Signaling need: Costly signals and animal welfare assessment. Appl. Anim. Behav. Sci. 44:159-169.

White R.G., DeShazar J.A., Tressler C.J., Borcher G.M., Davey S., Waninge A., Parkhurst A.M., Milanuk M.J. \& Clemens E.T. 1995. Vocalization and physiological response of pigs during castration with or without a local anaesthetic. J. Anim. Sci. 73:381-386.

Wöhr M. \& Schwarting R.K.W. 2007. Ultrasonic Communication in Rats: Can playback of 50-kHz calls induce approach Behavior? PLoS ONE 2:1-12.

Yáber M.C. \& Herrera E. 1994. Vigilance, group size and social status in capybaras. Anim. Behav. 48:1301-1307. 